\title{
A NEW GENUS OF MAYFLIES FROM THE MIOCENE OF FLORISSANT, COLORADO.
}

\author{
By T. D. A. Cockerell. \\ University of Colorado, Boulder, Colo.
}

Among some fossil insects from Florissant kindly loaned by Director J. D. Figgins of the Colorado Museum of Natural History, I find a very fine Ephemerid belonging to the Siphlonuridæ* and apparently referable to an undescribed genus. Banks, in 1907, treated Chirotonetes and Ameletus of Eaton as synonyms of Siphlonurus. On this broad basis the fossil might also be referred to Siphlonurus; but more recent authors have recognized Eaton's segregates, and from this point of view Siphlurites forms a sufficiently valid genus. In the description, I have followed Tillyard's revised nomenclaturet, but it should be understood that Tillyard's first and second cubitus are Comstock's first and second anals (following Miss Morgan); Tillyard's media is Comstock's cubitus, and Comstock's media is considered part of the radius. In Needham's key to the genera Siphlurites runs out on p. 25 at ff, forming a third section as follows:

fff. The intercalaries between the first and second anal veins (of Needham and Comstock) represented by a pair of veins, the first simple, the second forking, from the first anal to the wing margin, and a third vein which bends and runs a long course parallel with the first anal, emitting below about nine simple veins to the margin . Siphlurites.

\section{Siphlurites new genus}

Anterior wings with costa somewhat arched basally, the costal area broadened, so that its depth is $1 \mathrm{~mm}$., gradually decreasing apicad; transverse veins of costal area numerous

\footnotetext{
*Tillyard writes Siphluridae, but Eaton named the type genus Siphlonurus in 1868, and was not at liberty to alter it to Siphlurus in 1871

† Transactions New Zealand Institute 54. (1923) p. 227.

$\$$ Bull. 86, New York State Museum (1905) pp. 23-26.
} 
in subbasal region, forming cells which are twice as high as long, but beyond they become widely spaced, forming cells which are much longer than high; subcosta in subbasal region very close to radius, gradually diverging from it, so that near middle of wing the subcosta is equally distant from costa and radius; radial sector with four very oblique branches, the first forking a little over $6 \mathrm{~mm}$. from end, and including within the forks a supplementary longitudinal vein; the second and third branches of the radial sector originate close together, but the origin of the third, though delicate, is not obsolete; the fourth, arising about $7.6 \mathrm{~mm}$. from end of wing, starts downward at nearly a right angle with the sector, and then bends distad; between it and the sector are three supplementary veins, the first long, the two lower shorter; media branching about $3.7 \mathrm{~mm}$. from base of wing, the fork very acute, and between the branches a long supplementary vein, and near the margin four short very delicate supplementary veins, two above and two below the main supplement; cubitus with main (upper) part strong, slightly curved subapically, emitting about five cross veins to the strongly arched second cubitus, then two long veins (the second forked) to margin, then, beyond level of end of second cubitus, a vein which curves distad travelling to the margin parallel with the first cubitus, and emitting about nine oblique veins below. Hind wings developed, but the details cannot be made out. Type the following.

Siphlurites explanatus, sp. nov.

Length from front of head to end of abdomen $21 \mathrm{~mm}$; expanse $44 \mathrm{~mm}$.; length of anterior wings $21 \mathrm{~mm}$., the width about middle $7.7 \mathrm{~mm}$; eyes to base of wings $1.7 \mathrm{~mm}$., the prothoracic region short and broad (it is considerably longer in Ephemera howarthi.) Head and thorax brown; wings hyaline, with pale brown veins; a slight suggestion of mottling along costa

Miocene shales of Florissant.

Scudder described five species of Ephemerid nymphs from Florissant; so far as can be seen, they suggest the genera Ephe- 
merella, Hexagenia, Potamanthus and Bactis. Two species have been described from adults. Ephemera exsucca Scudd. has an expanse of only $16 \mathrm{~mm}$.; $E$. howarth $i$ Ckll has three strong tails, as in true Ephemera. In the somewhat arched costa and broad costal area Siphlurites agrees with Cronicus anomalus (Pictet) from Baltic amber, but is is otherwise quite different.

It is worthy of note that in the Permian Protereisma and Protechma of Sellards the first cubitus emits a couple of veins at very acute angles (not curved at base as the long branch of Siphlurites), and these proceed distad to the margin, subparallel with the first cubitus. Thus the special feature of Siphlurites may be regarded as primitive. The Permian insects constitute a distinct family Protereismatidæ, having the lower wings almost or quite as large as the upper. 

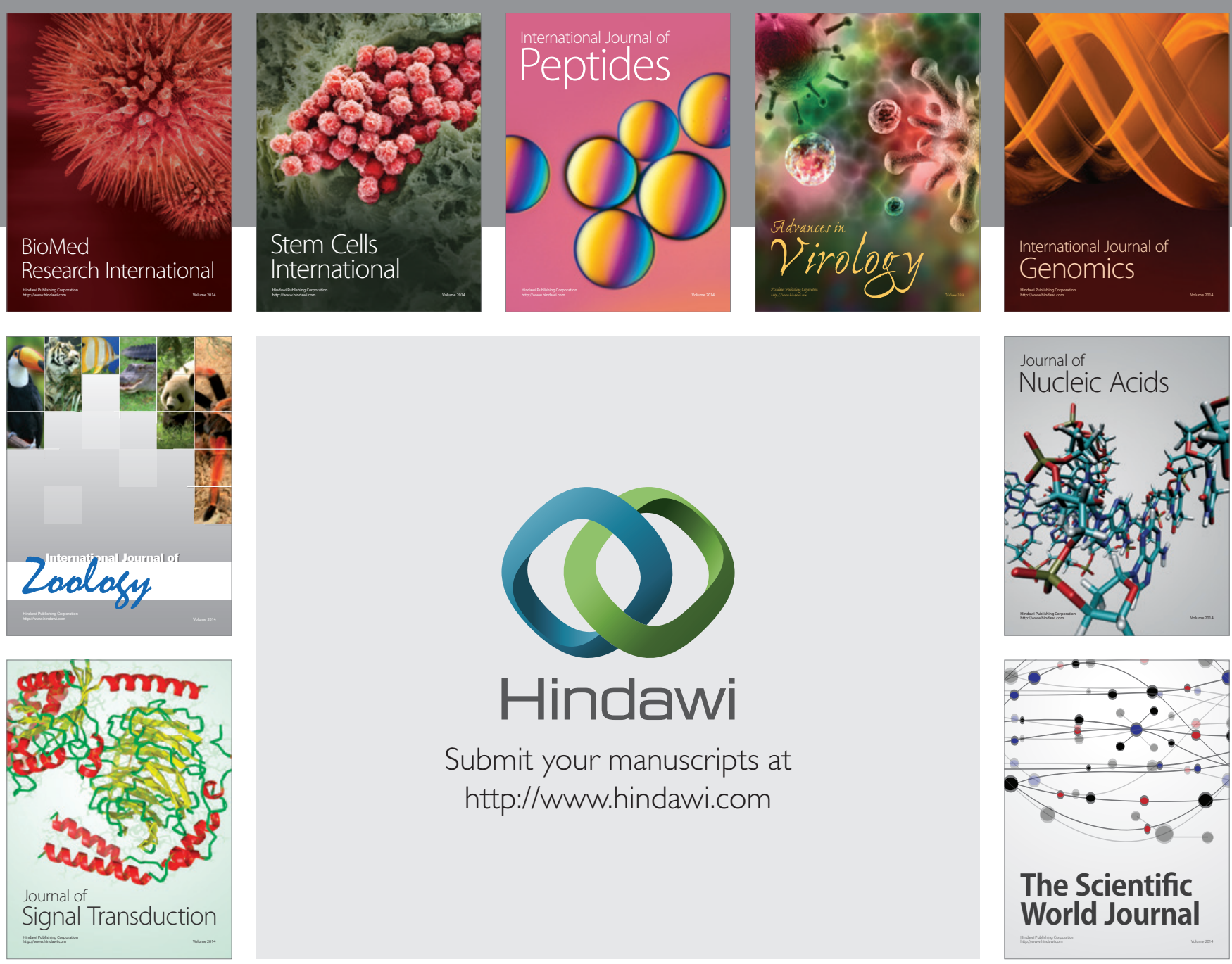

Submit your manuscripts at

http://www.hindawi.com
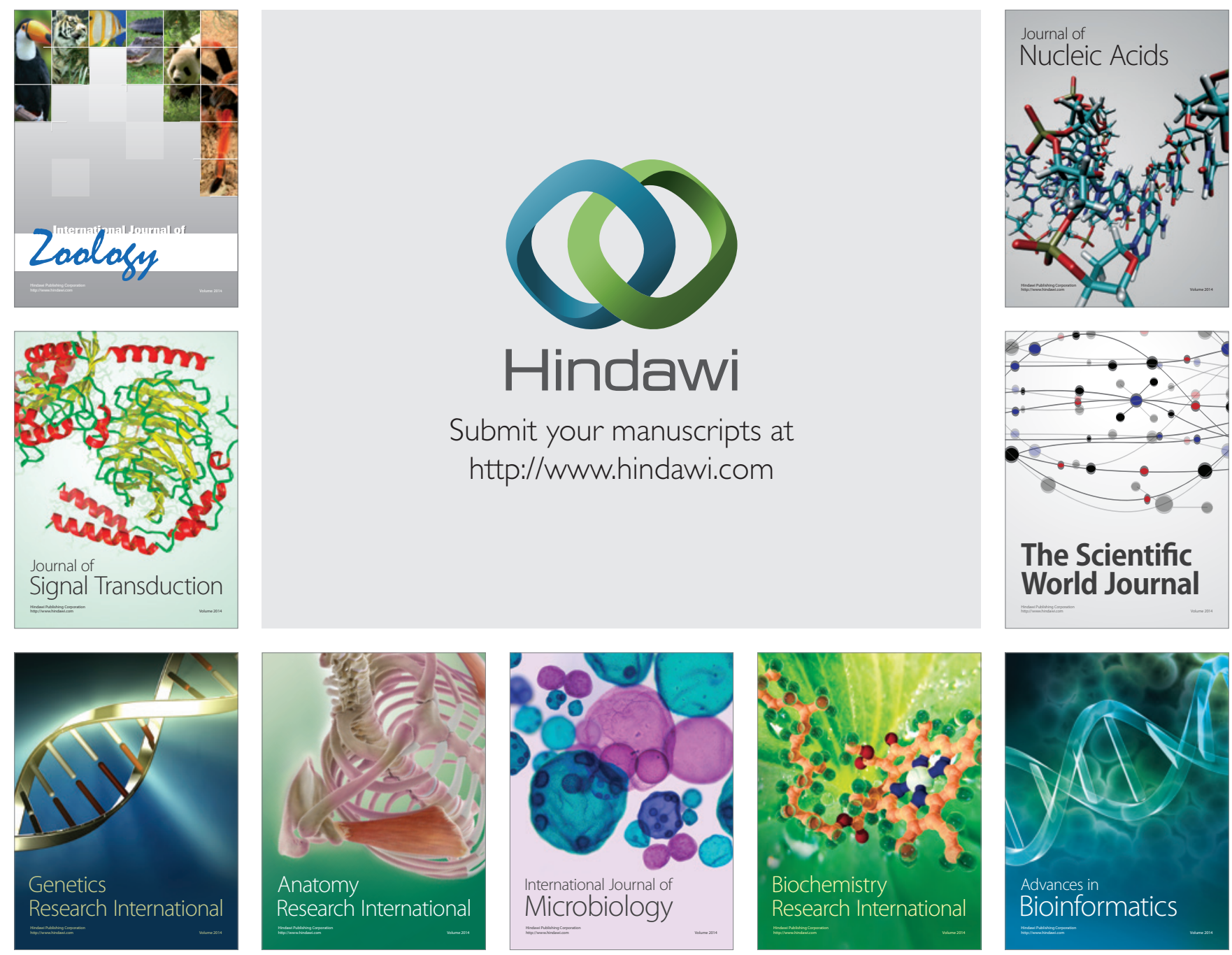

The Scientific World Journal
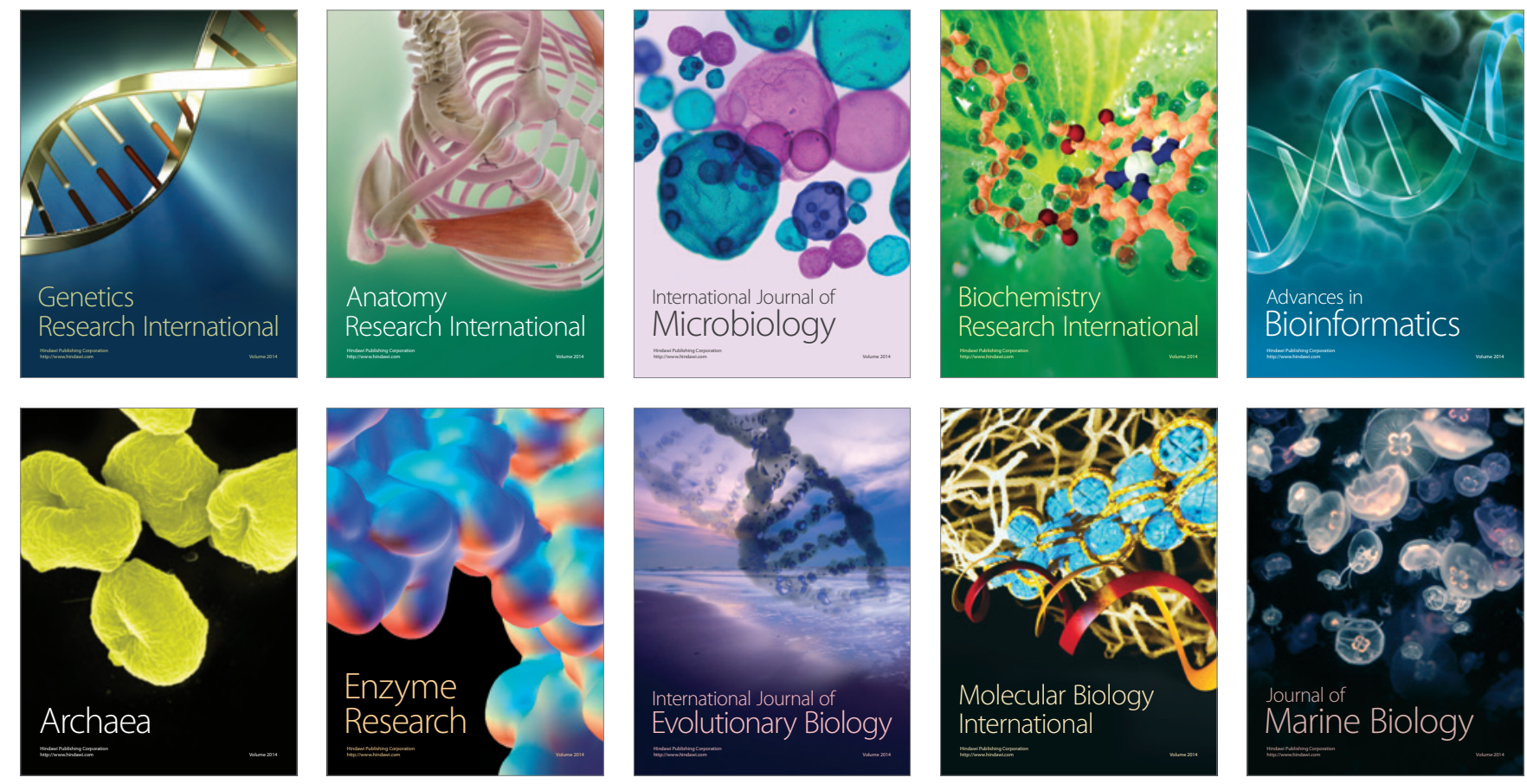